\title{
Chapter 7 \\ China's Legal Response to Trafficking in Wild Animals: The Relationship between International Treaties and Chinese Law
}

\author{
Jiwen Chang
}

\begin{abstract}
The chapter gives an account of China's new legal framework (particularly the Wild Animal Protection Law of 2016). This comprises novel official decrees which interpret the criminal law, law enforcement activities (partly police operations conducted jointly with other states), new injunctions banning ivory products, and finally criminal prosecutions. However, gaps and deficiencies persist in China's law on the books, enforcement remains slow and patchy, and international cooperation is not strong. Chang suggests several concrete measures for improvement, including the introduction of public interest litigation, better coordination among governmental departments, a trading information platform, and consultation with the secretariat of the Convention on International Trade in Endangered Species of Wild Flora and Fauna (CITES), in order to bring the Chinese legal and administrative framework fully in line with CITES.
\end{abstract}

\section{Introduction}

In China, the wild animals and animal products that are sold through illegal trafficking are mainly those that can be made into medicines; are raw materials in the form of ivory, rhinoceros horns, and turtle shells; and are edible or have ornamental value, such as birds, monkeys, turtles, and lizards. Due to its rapid economic development over the past decade, China has become one of the world's largest wildlife markets. The main reasons for trafficking are a lack of viable

Revised version of the original published article "China's Legal Response to Trafficking in Wild Animals: The Relationship between International Treaties and Chinese Law" by Jiwen Chang, American Journal of International Law Unbound, Volume 111, 2017, pp. 408-412. The original article was published as an Open Access article, distributed under the terms of the Creative Commons Attribution licence (http://creativecommons.org/licenses/by/4.0/).

J. Chang $(\bowtie)$

Chinese Academy of Social Sciences, Institute of Law, Beijing, China

(C) The Author(s) 2020

A. Peters (ed.), Studies in Global Animal Law, Beiträge zum ausländischen

öffentlichen Recht und Völkerrecht 290,

https://doi.org/10.1007/978-3-662-60756-5_7 
substitutes for raw materials used in traditional Chinese medicines (e.g., bear bile, bear bile powder, pangolin, and other products); a preference in traditional food culture for delicacies made from wildlife; and of the private consumption by some rich and corrupt government officials of tiger's meat, bear's paw, pangolin and other wild animal products - bear's paw and pangolin being the most popular. This type of wild animal trafficking endangers the safety of animal species protected by the Convention on International Trade in Endangered Species of Wild Fauna and Flora (CITES), and damages the international image of the government and people of China. Since 2013, under the frame of construction of ecological civilization, China has taken stricter measures on legislation, administrative enforcement, judicial adjudication, and international cooperation on prevention and punishment of illegal trafficking.

\section{China's Law Enforcement and Judicial Measures Against the Trafficking of Wild Animals and Their Products}

\subsection{Law Enforcement Measures}

China joined CITES on December 25, 1980, and on April 8, 1981, CITES came into force for China. China has increased its efforts to implement CITES with the enactment of the Wild Animal Protection Law and the creation of special customs and criminal regulations.

The Chinese government has strictly implemented wild animal protection laws and regulations, and now cracks down on trafficking, defends the honour of the nation, and protects the ecological balance. From January 6 to February 5, 2013, China and 21 other Asian and African countries organized an operation, codenamed "Cobra," against international wildlife crime. The operation resolved 71 cases, arrested 85 suspects, and seized $185 \mathrm{~kg}$ of ivory, $13 \mathrm{~kg}$ of rhino horns, about $50 \mathrm{~kg}$ of pangolin scales, and 76 rhinoplax vigil beaks. Operation "Cobra II," coorganized with twenty-eight Asian, African, and North American countries, was conducted from December 30, 2013 to January 26, 2014. It resulted in the seizure of $286 \mathrm{~kg}$ of ivory, 802 pieces of reticulated python skin, and $120 \mathrm{~kg}$ of pangolin scales. ${ }^{1}$ In January 2014, the Chinese government publicly destroyed 6.1 tons of confiscated ivory in Dongguan City of Guangdong province for the first time, and in the year after, the Chinese government, again publicly, destroyed $662 \mathrm{~kg}$ of ivory. ${ }^{2}$

\footnotetext{
${ }^{1}$ Chinese State Forestry Administration, 'China Customs' Special Action on Combating Wildlife Smuggling', 9 June 2015, available at: http://www.forestry.gov.cn/wlmq/3585/content-773841. html.

${ }^{2}$ Yang, 'Save Endangered Wildlife, Fight Against Trafficking, We Are on the Way' 2015.
} 


\subsection{Judicial Measures}

China's consciousness of ecological civilization and laws will need to improve over time. Although the Chinese legislature has banned ivory imports with the Wild Animal Protection Law, wildlife poaching and trafficking have yet to be eliminated entirely. Several typical criminal cases in recent years have, however, had a significant social impact. In November 2014, a farmer in Henan Province was sentenced to three months detention for capturing 87 toads. The farmer was the first person to be punished in such a case. ${ }^{3}$ Two years later, some farmers were also sanctioned for capturing frogs. In November 2015, a college student from Henan province was sentenced to 10.5 years in prison for hunting and selling hobby falcons. These activities had not been previously treated as crimes. With constant public education and strict law enforcement, wildlife poaching and trafficking have been greatly reduced. Young people in particular tend to have lost interest in obtaining wild animals and their products. In the long run, poaching and trafficking will therefore likely continue to decline. ${ }^{4}$ In China's vast rural areas, wild animals that had largely disappeared for two or three decades have begun to reappear, indicating the effectiveness of China's ecological protections.

\section{New Chinese Legislation on the Elimination of Trafficking of Wild Animals and Their Products}

\subsection{Interpretation of Crimes Against Wild Animals by the Standing Committee of the National People's Congress}

In 1997, China's criminal law stipulated conditions and penalties only for illegal hunting and killing, acquiring, transporting, selling, and trafficking precious and endangered wild animals and their products that are significantly protected by the state. As consumption drives these crimes, it is also necessary to combat illegal purchases in order to effectively protect wild animals from illegal hunting, transport, trafficking, and other such acts. On April 24, 2014, the Standing Committee of the National People's Congress adopted "Interpretation of Article 341, Article 312 under Criminal Law of the People's Republic of China," which specifies that it is a crime to purchase as food wildlife and wildlife products that are under special state protection. On February 6, 2017, China's internet spread a Hong Kong businessman's blog that showed that local government officials in Guangxi had

\footnotetext{
${ }^{3} \mathrm{Li}$, 'Capturing 87 Toads, A Farmer Gets Criminal Detention for Three Months' 2014.

${ }^{4}$ With the development of the internet and we-media such as we-chat, more and more cases have been reported to the government or exposed to the public. In addition, more and more cases are treated as criminal. This does not mean, however, that the occurrence of crimes such as poaching and trafficking is actually increasing.
} 
invited him to eat pangolin dishes in their office. The blog entry was shared quickly and led to condemnation. In February 2017, the businessman and the chefs who purchased pangolin were criminally detained on suspicion of illegal acquisition of precious, endangered wildlife.

\subsection{The Wild Animal Protection Law and Its New Provisions}

In order to combat the trafficking and illegal trade in wild animals at the source as well as the intermediate steps, the Wild Animals Protection Law (2016) prohibits the following activities: (a) producing or selling food that uses wild animals under national special protection and the products of such animals; (b) producing or selling food using wild animals not specially protected by the state and the products of such animals without evidence of the legal source; (c) illegally purchasing for food wild animals under national special protection and the products of such animals; and (d) illegally advertising wild animals and their products.

As regards international cooperation in the fight against wildlife trafficking, Article 36 of the Wild Animals Protection Law provides that the state has to organize international cooperation and communication activities regarding wildlife protection and related enforcement activities, to establish coordination mechanisms to prevent and combat trafficking and illegal trade in wild animals and their products, and to conduct operations to combat trafficking and illegal trade. This provision lays down the legal foundation for China to better fulfil its duties under CITES and to combat wildlife smuggling more comprehensively.

As regards public participation, Article 5 of the Wild Animals Protection Law stipulates that "the State encourages citizens, individuals and other organizations to support wildlife protection public welfare activities by participating in wildlife protection activities through donation, subsidy and volunteer service." At present, "Let Birds Fly," "China Finless Porpoise Protection Action Network," "Friends of Nature," and other NGOs as well as some environmental activists, participate in the protection of birds. Their work attracted Chinese Central Television, the local television, and other news media to support, or to join in, thereby helping the public security bodies to arrest suspects. For example, on February 26, 2017, the Guangxi police seized seventy wild turtles in a rented house ${ }^{5}$ on the border between China and Vietnam based on a tip.

\subsection{Ban on Ivory and Its Products in Recent Years}

Since the end of 2012, the Chinese government has advocated ecological civilization and has strengthened its international cooperation on wildlife protection. On February 26, 2015, the State Forestry Administration announced that China had

\footnotetext{
${ }^{5}$ Yan/Huabin/Qiuhong, 'Suspected of Smuggling Wildlife' 2017.
} 
implemented two temporary injunctions: first, a prohibition on African ivory carvings after CITES entered into force; second, a prohibition on the import of memorial ivory originating from hunting in Africa. During the import injunction, the State Forestry Administration had to suspend the relevant administrative licensing matters. On March 2, 2015, Chinese President Xi Jinping met Prince William of Great Britain and introduced him to China's policy and to its work on protecting wild animals such as elephants, hoping to enhance international cooperation in this field. ${ }^{6}$ Two days later, Prince William visited Xishuangbanna, a city in the Yunnan province, to examine the status of elephant protection. ${ }^{7}$ On September 25, 2015, Xi Jinping and United States President Barack Obama, as leaders of the two major destination countries for ivory trading, agreed to enact a domestic ban. Each country is required to take effective and timely action to ensure the gradual cessation of ivory import and export trade (except in a few special cases). On December 2, 2015, Xi Jinping visited Zimbabwe's wild animal rescue base. Xi Jinping committed China to continue to support the strengthening of the protection of wild animals through material assistance, the exchange of experience and so on. It is evident from these undertakings that China's diplomacy and international cooperation on wildlife protection has changed from passive adaptation to active participation.

When the two temporary injunctions on ivory products expired in March 2016, the State Forestry Administration immediately announced more stringent control measures for imports of ivory and its products. The implementation of the two temporary injunctions has been extended to December 31, 2019, and the scope of prohibited imports of ivory and its products has been expanded.

Where there is a market, there will inevitably be some overseas trafficking and poaching. The General Office of the State Council promulgated the Notice of Stopping Commercial Production and Sales of Ivory and Products by decree on December 30, 2016, requiring the closure of commercial processing and sales of ivory and its products in stages and in groups. Specifically, China shut down several processing and sales units for ivory and its products by March 31, 2017 and will fully stop the relevant activities by December 31, 2021. This measure will put many ivory engravers out of work, and many lawful collectors will have difficulty selling the ivory art works that they own, leading to huge losses. There has been to date no information on government compensation for ivory engravers. However, no ivory engraving companies and operating companies are heard to complain in public as of July, 2018. It is thus clear that Chinese society has a consensus on wildlife conservation. Although Donald Trump, the President of the United States, decided to relax restrictions on ivory imports from some African countries, The President Xi of China acted as a firm environmentalist. The Chinese government has no signs of lifting the ban of the international and domestic ivory trade as of July, 2018. Some international organizations commented that the Chinese government is becoming one of the world

\footnotetext{
${ }^{6}$ Liu, 'Xi Jinping Met with Prince William' 2015.

${ }^{7} \mathrm{Hu} /$ Yang, 'British Prince William Visits Xishuangbanna' 2015.
} 
leaders in the field of wildlife conservation. ${ }^{8}$ Thus, in order to protect the African elephants, China has paid a huge price.

\section{Suggested Improvements to China's Legal Response to Trafficking}

First, the Chinese wildlife protection list is not consistent with the CITES appendix. The Wild Animal Protection Law protects wildlife by classification, focusing on precious, endangered wild animals. National specially protected wild animals are divided into two classes of wildlife protection. The list of national specially protected wild animals must be formulated and adjusted every 5 years, based on the scientific assessment of the department of wildlife protection as approved by the State Council. Some wild animals highly valued in the market, such as black bears and pangolins, are among the protected animals listed in Appendix I of CITES, but only classified as wildlife under the second class protection under Chinese law, making their level of protection lower than it should be. As pangolins are endangered in China, these should be included in the first class protection list, as should wild black bears. These adjustments would help to crack down on trafficking.

Second, protection levels sometimes differ between wildlife and artificially bred wild animals. Avery controversial provision in Article 28 of the Wild Animals Protection Law requires wild animals with mature and stable artificial breeding technology to be entered on the list of protected artificially bred wild animals formulated by the State Council wildlife protection authorities based on scientific justification. According to the relevant wild population protection cases, the artificial population of such wild animals may no longer be included in the national specially protected wildlife list and is subject to different management measures than the wild population. According to Article 28, if the black bear's artificial breeding technology has matured and the number of wild black bears is relatively stable, then artificially bred black bears are not to be treated as wild animals, and thus illegally purchasing or trafficking artificially bred black bears will not constitute the illegal acquisition or trafficking of precious and endangered wildlife. This reasoning may diverge from the intent of CITES. CITES provides that reared tigers, bears, and other animals continue to be included in the national specially protected wildlife list. Moreover, research into artificial substitutes for bear bile should be strengthened. China should prohibit the extraction of bear bile within fifteen years and gradually eliminate trafficking in black bear and bear bile products.

Third, a lack of regulatory personnel and a limited regulatory capacity makes it difficult to find and combat all trafficking. One suggestion is that wildlife protection regulators and public security organs promote public participation and supervision by establishing measures to reward reporting. The information that the public submits

\footnotetext{
${ }^{8} \mathrm{Bo} / \mathrm{Ke}$, 'Chinese government is becoming one of the world leaders in the field of wildlife conservation' 2018.
} 
must be taken seriously or the relevant manager should be held accountable. Other suggestions are establishing a shared platform for regulatory information across various departments and regions and directing the interdepartmental and interregional regulatory cooperation mechanism toward joint or collaborative law enforcement. Furthermore, in the next reform of the Wildlife Protection Law, clear provisions for a system of public interest civil litigation should be proposed. This would allow social organizations and individuals to prosecute the trafficking, poaching, sales, and transport of wild animals and their products and to make offenders liable for ecological damage.

Fourth, some law enforcement agencies are inactive or slow to act when dealing with illegal activities. Some offenders even sell wild animals and their products near local industrial and commercial departments, public security police stations, and county or town governments without being subject to any control. To solve the prevarication between the local government and the regulatory authorities, the state should first establish a list of regulatory powers for the local government and for the departments of forestry, public security, customs, business, and environmental protection. The state would provide that these no longer be exempt from liability for dereliction of duty in accordance with this list. China should establish a system for assessing local government's performance annually with respect to wild animal protection. Local governments should be held accountable for abusive action, slow action, and inaction by law enforcement agencies. A further suggestion is that in the next amendment of the Wild Animal Protection Law, clear provisions for a system of public interest administrative litigation be proposed. This would allow social organizations and individuals to sue local government and its regulatory authorities for abusive action, slow action, and inaction. Only in this way can these authorities be compelled to supervise in keeping with the law. In addition, a third-party assessment system is needed. NGOs and other third parties could thereby assess the government's performance as regards law enforcement.

Fifth, the mechanism for international antitrafficking cooperation needs to be refined. Under the coordination of the State Forestry Administration, NGOs at home and abroad should strengthen their communication and cooperation in the protection of wild animals and the fight against trafficking, poaching, illegal transport, and sales by forming an information network to combat trafficking of wild animals beyond national borders. As coordinated by the State Council, the departments of forestry, industry and commerce, customs, environmental protection, and public security should jointly create a list of regulatory powers in the fight against the smuggling and illegal trade of wild animals and their products. This would refine the coordination mechanism among departments in order to establish a unified information platform regarding wildlife in international and domestic trade. Furthermore, under the leadership of the Ministry of Foreign Affairs, a mechanism for international negotiations and cooperation and a unified information platform regarding transnational law enforcement should be collaboratively established, based on the coordination of the departments of forestry, industry and commerce, customs, environmental protection and public security. In addition, the Chinese government should consult with the CITES Secretariat and in particular should strengthen communication with the countries of origin and transport of wild animals and their products. As regards cross-border trafficking, China's communication, coordination, 
and notification mechanism should be improved jointly by signing bilateral or multilateral treaties with important neighbouring countries and major trading partners and by establishing the mutual convergence of law enforcement. Only in this way can trafficking and illegal trade be systematically curbed.

Finally, the government should plan to compensate ivory engravers for ceasing the commercial production and sales of ivory and products and help them make the transition to other livelihoods. Without this assistance, black markets will continue to exist, at least in the near future.

\section{Conclusion}

China now has strict legislation on the protection of wild animals. The next step is to enforce the law through the measures discussed. China should strengthen its publicity, education, and social participation on these issues and ensure that law enforcement is continuous, strict, and uniform across all districts. China's international cooperation in wildlife protection would thereby achieve better results. Moreover, it is only in this way that China can gain international recognition for acting as an environmentally responsible country.

\section{References}

Bo, W., \& Ke, T. (2018, April 28). World Animal Protection, 'Chinese government is becoming one of the world leaders in the field of wildlife conservation'. The Paper.

Hu, C., \& Yang, Y. (2015, March 4). British Prince William Visits Xishuangbanna and has "Intimate Contact" with Elephants. Xinhua.

Li, Z. (2014, December 1). Capturing 87 toads, a farmer gets criminal detention for three months. Dahe.

Liu, H. (2015, March 3). Xi Jinping Met with Prince William. Xinhua Daily Telegraph.

Yan, C., Huabin, Z., \& Qiuhong, H. (2017, March 1). Suspected of smuggling wildlife, a Man's Bribe of 300 Thousand Yuan seeking "Exception" was rejected'. Guanxi News.

Yang, S. (2015, July 3). Save endangered wildlife, fight against trafficking, we are on the way. China Daily.

Jiwen Chang is a deputy director at the Research Institute of Resources and Environment Policies of Development Research Center of the State Council as well as a professor at the Institute of Law of Chinese Academy of Social Sciences. He is also a part-time professor at China University of Geosciences (Beijing) and Capital University of Economics and Business. He is a member of the Standing Committee of Beijing Municipal Peoples' Congress. His current research interests relate to animal welfare law, environmental policy and law. 
Open Access This chapter is licensed under the terms of the Creative Commons Attribution 4.0 International License (http://creativecommons.org/licenses/by/4.0/), which permits use, sharing, adaptation, distribution and reproduction in any medium or format, as long as you give appropriate credit to the original author(s) and the source, provide a link to the Creative Commons licence and indicate if changes were made.

The images or other third party material in this chapter are included in the chapter's Creative Commons licence, unless indicated otherwise in a credit line to the material. If material is not included in the chapter's Creative Commons licence and your intended use is not permitted by statutory regulation or exceeds the permitted use, you will need to obtain permission directly from the copyright holder. 